\title{
Alternative Control Methods of Gastrointestinal Nematode Infections in Small Ruminants: Biological Method and Use of Medicinal Plant Extracts
}

\author{
Ermias Worku*, Ashenafi Kiros, Hagos Asgedom, Biniam Tadesse \\ National Animal Health Diagnostic and Investigation Center, Sebeta, Ethiopia
}

*Corresponding Author: Ermias Worku, National Animal Health Diagnostic and Investigation Center, Sebeta, Ethiopia, Email: nafikwegmail.com

\begin{abstract}
Diseases caused by gastrointestinal nematodes (GINs) in livestock are a major production constraint, causing economic losses, especially in small ruminants in the tropics and subtropics. The infection of sheep and goats by nematodes is rampant in most African countries, where the environmental conditions are conducive to nematode growth and transmission. In general, GINs reduce productivity of small ruminants due to lowering fertility, reduction in milk production and loss of weight when feed intake is reduced. Currently, the conventional control strategy for GIN infections is the use of synthetic anthelmintic drugs. However, several problems associated with the use of these anthelmintics have been observed worldwide. Among these problems, development of drug resistance to the available drugs is widespread. Development of resistance has been attributed to the extensive therapeutic use of anthelmentics. Consequently an alternative control measures are much needed. Medicinal plants may become good alternatives for modern synthetic anthelmintics if their efficacy is proved scientifically under controlled studies. Plant-based drugs are believed to be less toxic to the host and end-users, easily available, biodegradable, cheaper and eco-friendly. Several families of plants such as the Lamiaceae, Caesalpiniaceae and Meliaceae are being investigated for their efficacy against various helminth parasites. Methodologies used for treating animals with plant materials includes the provision of fresh, conserved or dried plants, the use of crude aqueous and solvent extracts and administration of fractionated materials from the crude products. In addition to herbal medicines, biological agents have shown positive results in controlling GINs such as fungus Duddingtonia flagrans and bacterium Bacillus thuringiensis. The objective of this review is therefore to highlight some advances in the study of herbal medications and biocontrolling agents including the methodology as well as outlines future research fields.
\end{abstract}

Keywords: Anthelminthics, Biological control, Helminthes, livestock, medicinal plants, nematodes

\section{INTRODUCTION}

Infections by gastrointestinal helminth parasites of livestock are among the most common and economically important diseases of grazing livestock. They are characterized by lowering outputs of animal products (meat, milk, hides and skins), manure and traction (Perry et al., 2002). In the Developed world, with the exception of those countries in the southern hemisphere, the greatest impact is probably the costs of control, particularly in the case of the helminth parasitoses. In the Developing world, the greatest impact of parasitic diseases is attributed to the potential productivity losses. In addition, there are highly pathogenic nematode (Haemonchus spp), and trematode (Fasciola spp) of ruminants which are also capable of causing acute disease and high mortality (Githiori, 2004). Haemonchus contortus is one of the top 10 constraints of sheep and goat production in East Africa.

The current methods of gastrointestinal nematode (GIN) control are based on repeated use of synthetic anthelmintic drugs (such as Benzimidazoles, Imidazothiazoles and macrocyclic lactones). However, with increasing exposure by routine dosage of small ruminants, GIN are developing resistance to most commercial anthelmintic drugs (Coffey et al., 2007). Resistance to anthelmintics is demonstrated by the ability of GIN to survive drug treatments that used to be effective against 
the same species and stage of infection (Coffey et al., 2007). Secondly, consumers of animal products have also become cautious of possible contamination of meat and milk products by residues of drugs. At the other end, small-scale farmers are being pushed out of the small ruminant farming by GIN due to their inability to treat them effectively because of the high price of effective drugs. There is a need to re think the use of anthelmintics, as well as develop novel approaches, which will lead to sustainable control of parasites. Ideally, this may entail an integrated approach, including reduced frequency of anthelmintic treatments, biological control, parasite vaccines, livestock breeds that are resistant to parasites and the use of plants with anti-parasitic properties(Waller, 2003).

Biological control is becoming an important non-chemical option for controlling GIN in animals since biocontrol agents can control a target organism by reducing its population to a level that no longer causes clinical problems and economic losses. In addition, biocontrol agents have low mammalian toxicity, high efficacy, naturally occurring and multiply to a level that matches its target organisms (Larsen, 2006). Thus, biocontrol agents can avoid the issue of chemical residues in food and is an attractive option for organic farming. However, there are no commercial biocontrol agents currently available for controlling GIN in livestock anywhere in the world.

Traditional medicines hold a great promise as sources of easily available effective anthelmintics agents (Temjenmongla and Arum, 2005). Most of these plants are readily available in the tropical and sub-tropical region that may be affordable to all farmers including smallholder farmers (Akhtar and Malik, 2000). In ethnoveterinary medicines, which draw inspiration from traditional practice, there seems to be a range of plants or plant extract suitable for treating almost every parasitic disease of livestock (Athanasaidou et al., 2007). Research for biocontrolling agents and traditional medicinal plants in treatment of parasitic gastrointestinal nematodes is still in progress.

The objective of this seminar paper is therefore to highlight current knowledge on the research and application of medicinal plant extracts and biocontrol agents as alternative medication to modern chemotherapy against GI nematode parasites of small ruminants.

\section{Gastrointestinal NeMATOde}

\subsection{The Parasites and Their Epidemiology}

Gastrointestinal nematodes are the most damaging parasites in small ruminants (Abuda et al., 2010). In Africa, particularly, the infection in most cases is by members of the class nematoda. The major ones include: Haemonchus contortus, Trichostrongylus colubriformis, Bunostomum trigonocephalum and Oesophagostomum spp. Most of these parasite species have been reported from different areas of Africa including Ethiopia (Waller, 1997). Animals raised in confinement or on pasture-based systems will almost certainly be exposed to gastrointestinal parasite at some point in their lives (Min and Hart, 2003). All types of livestock are at risk to gastrointestinal nematode infection which varies in their host range, life cycle and severity. However, small stock is the most susceptible to gastrointestinal nematode infections (Tsotetsi \& Mbati, 2003).

The nematode life cycle (Figure 1) may be direct or may include an intermediate host. Sexes are usually separated (male and female). However, the economically important gastrointestinal parasites (Strongylid) in sheep and goats have direct life cycles, with no intermediate host (Sissay, 2007). Mature parasites (worms) breed inside the host and lay eggs which are shed in faeces. After eggs pass out of the host, they hatch into first-stage larvae (L1), which grow then moult into second-stage larvae (L2) under appropriate conditions of temperature and humidity. Larvae need moisture to develop and move. During this time, larvae (L2) feed on bacteria, and then moult into infective larvae (L3), which migrate out of faeces and climb up blades of grass. The time for development from egg to infective larvae can be as short as 7-10 days, especially during summer. Further, when an animal (sheep or goat) grazes, it may ingest parasitic larvae along with the grass. Normally the L3 stage larvae moult into fourth-stage larvae (L4) within 2- 3 days, then after a further 10-14 days, they moult into young adult parasites (Hale, 2006; Coffey et al., 2007). The time from ingestion of infective larvae to adult laying eggs, called the pre-patent period, vary among nematode. 


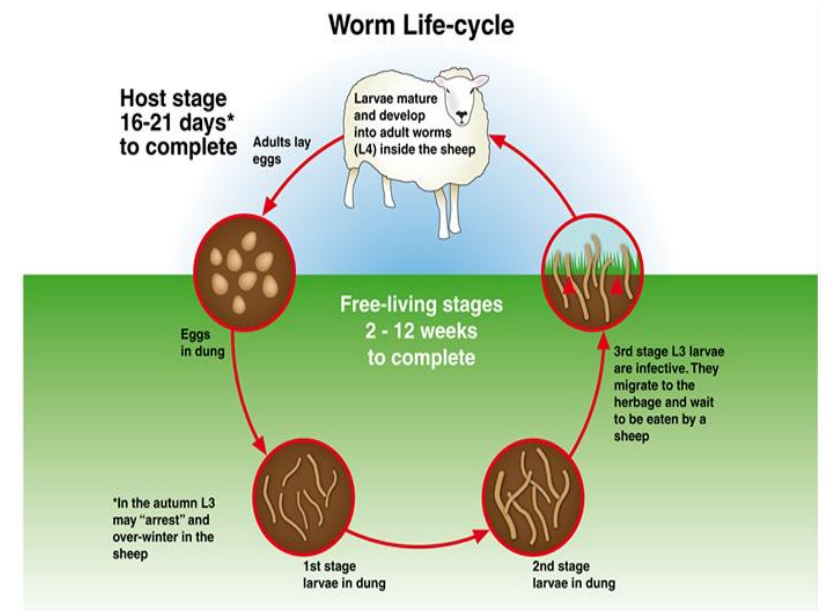

Figure1. Life cycle of gastrointestinal nematodes of small ruminants. (Scheuerle, 2009).

The development, survival and transmission of the free-living stages of nematode parasites are influenced by micro-climatic factors within the faecal pellets and herbage. These include sunlight, temperature, rainfall, humidity and soil moisture. Under optimal conditions (high humidity and warm temperature), the development process takes 7 to 10 days, but for $H$. contortus a more rapid translation of eggs to larvae can occur in warm wet conditions. Infective stage of nematode can survive for weeks to months on the pasture depending on the weather conditions and the nematode species (Stromberg and Averbeck, 1999).

\subsection{Pathological Impact and Diagnosis}

Nematodes usually live in the digestive system of host animals, affecting the absorption and/or retention of minerals especially phosphorus (Coop and Kyriazakis, 2001). Effects of nematodes on the host include loss of condition, rough coat, diarrhoea, bottle jaw, anaemia and death (Hale, 2006). Moreover, clinical signs such as diarrhoea, weight loss and loss of appetite can be indicators of nematode infection, especially in young animals (Sissay, 2007). Livestock nematodes have economic consequences when their numbers rise under suitable conditions ( $\mathrm{H}$ ale, 2006).

Parasitism by nematodes results in the loss of host protein like plasma and frequently erythrocytes exfoliated epithelial cells and mucus. A Pale to grayish colouring of mucus membranes like eye lids, gums, and vulva, can be seen due to lack of red blood cells. Nematode parasites also affect digestion, energy and nitrogen utilization in the parasitized animal and reduce the performance of the host and feed consumption (Simcock et al., 2006).
Diagnoses of nematode infection in the host can be done by examination of the host faeces for parasitic eggs and larvae (Knox and Faedo, 2001). Demonstration of parasite eggs or larvae in the faeces or faecal culture provides evidence that the host is infected, but does not indicate the level of infection (Hansen and Perry, 1994). Heavy nematode infection is indicated by finding more than a thousand eggs per gram (EPG) of faeces. Between 200 and 800 EPG of faeces would count as a moderate nematode infection. However, the level of infection from faecal egg or larvae counts is variable in each country or region, according to weather conditions and the nematode's specific pathogenicity (Lindqvist et al., 2001).

\subsection{Economic Importance of Parasitic Gastrointestinal Nematodes}

Parasitic gastrointestinal nematode infections are of major economic importance resulting in heavy production losses in small ruminants than cattle. According to Eguale et al. (2007), gastrointestinal nematode infections accounts for $28 \%$ mortality and $8 \%$ of weight loss in sheep mostly in developing countries with poor socio economic status and poor management practices. Infected animals produce less quality of wool, meat and milk due to the observed clinical symptoms (Iqbal et al. 2010). Rate of production is also hampered because reproduction performances of infected animals are affected (Nchu et al. 2011).

Losses due to GIN parasitism estimated by governmental organizations extend into millions of dollars per year, but it is difficult to assess these losses because there are many factors involved. Such factors and their interaction include nutrition, environmental stress, genetics, 
management and concurrent disease. For example, in New Zealand, it was estimated that NZ\$200 million of production annually was still not being realized after taking into account the cost of nematode parasite control (Vlassov et al., 2001); in Australia, with increasing anthelmintic resistance, estimated losses were up to $\mathrm{AD} \$ 700$ million annually (Besier and Love, 2003); and Ethiopian meat markets and the export of livestock have an estimated annual loss of US\$400 million (Kumsa, 2006).

\subsection{Major Control Methods}

\subsection{1. anthelmintics}

Anthelmintic drugs are chemotherapeutic agents commonly used either for prophylactic purposes, in which the timing of treatment is based on a knowledge of the epidemiology, or for therapeutic purposes to treat existing infections or clinical outbreaks. Various groups of drugs such as Piperazine (ex. Piperazine salts), Benzimidazoles (ex. Albendazole), Salicylanilides (ex. Closantel), Macrocyclic lactones (ex. Ivermectin) and Imidazothiazoles (ex. Tetramisole) have been shown to be successful (almost 100\%) in eliminating most species of nematodes and trematodes during their early periods of utilisation, and some still remain effective in different parts of the world (Getachew et al., 2007). However, there are several evidences to show that resistance has already been developed or emerging against most of the anthelmintic groups by many species of nematodes (Chartier et al., 2001). Their long term utilization, inappropriate handling and under dosage may be some of the reasons for their reduced efficacy and for the increasing development of drug resistance. Development of anthelmintic resistance begins with the loss of efficacy of the drug on the nematodes which on later stages renders the expensive drug useless (Roeber et al. 2013).

Anthelmintic resistance is a threat to agricultural incomes because parasitic gastrointestinal infection rates only escalate and as a result heavy production losses will remain a major problem to livestock (Wolstenholme, 2004).

Benzimidazole, imidazothiazole and ivermectin all leave residues in meat, milk and their products. On the other hand, ivermectin is excreted in faeces in sufficient quantity to have a detrimental effect on invertebrates that usually degrade dung heaps, and hence on organisms higher up the food chain (De and Sanyal, 2009).
Moreover, where these drugs are not easily accessible either because of economic reasons or scarcity of veterinary services, as in most parts of Africa, animals die as a result of acute disease. These altogether urgently calls up on effective alternative or complementary methods of control.

\subsubsection{Alternative Control Methods}

Because of the above and other limiting factors, other means of gastro-intestinal nematode control have been explored such as using copper wire particles, grazing management, breeding for host resistance, vaccination, using plants extracts and biological control. Copper wire particles, Grazing management, breeding for host resistance, vaccination strategy, nutrition, biological control and use of medicinal plant extracts have been tried with varying success (Soli et al., 2010; Mitreva et al., 2007).

\section{BIOLOGICAL CONTROL AND USE OF Medicinal Plant Extracts}

\subsection{Biological Control}

\subsubsection{Concept of biological control}

In general, biological control of nematodes becomes an important, integrated element and sustainable strategies to control nematodes in livestock Biological control defined as the activity of natural enemies which include classical, un-exploited organisms and genetically modified organisms (Larsen, 2006).

Biological control might be different from other methods which are directed at the parasitic stages within the host. However, biological control is targeted at the free-living stages on pasture (Waller, 2006). This means that biological control focuses on the faecal deposits in which eggs, L1, L2 and L3 larval stages are found. The entire philosophy of using biological control agent against GIN nematodes in animals is to reduce the number of infective stages that are available to be picked up by grazing susceptible individuals of the different species of livestock (Waller, 2006). Biological control of nematodes in livestock aims to establish a condition where grazing animals are exposed to a low number of infective larvae and reduce the level of nematode parasitism in livestock so that natural immunity in the animals will tolerate these low levels (Epe et al., 2009). An important issue is that biocontrol agents have no negative effects on the environment. However the effect on animals requires investigation. Furthermore, biocontrol agents are free of chemicals, thus 
producers can capitalize on the residue-free, organic meat products that are in high demand from consumers and command a premium price (Waller, 2006).

Therefore, for the near future, the greatest research effort in the quest for biological control agents of animal nematode parasites is likely to be focused on those organisms in the external or free living, environment. This is because a large range of organisms can exert their effects indirectly, by habitat (dung) destruction, or directly by using the free living stages as a food source. Others have been suggested as potential candidates, such as earthworms, viruses, soil amoeba, protozoa, collembolans, mites, fungi, nematodes itself and bacteria (Thamsborg et al., 1999).

\subsubsection{Earthworms}

Earthworms are a vital component of the soil ecosystem. Earthworm populations consume large volumes of soil and organic matter, including animal faeces (Gronvold at al., 1996). During feeding, they consume nematodes present in soil and faeces. Earthworm actively participate in the destruction of eggs and larvae by digesting them or transferring them to deeper levels of the soil where chances that they can reach the surface as infective larvae are very low (Grønvold et al., 1996). However, these earthworms are only active in moist habitats, which limit their biological control potential. They may reduce transmission by degrading faecal pats but they may also prolog the survival of larvae by taking them into the soil.

\subsubsection{Dung Beetles}

The term 'dung beetle' refers to those beetles that live partly or exclusively on the dung of herbivorous; most species belong to the family Scarabaeidae. Adult beetles use the liquid contents of manure for their nourishment and some species form dung balls which they bury and lay their eggs in, others just live in the manure pats (Thomas, 2001). The activity of dung beetles is being discussed controversially: by breaking up the pats and partially burying the manure, they enhance the drying up of the dung which deteriorates growing conditions for larvae (Grønvold et al., 1996) but by the same activities in bad weather conditions they might help the larvae to survive by airing out the pats and thereby providing oxygen to the larvae (Vlassoff et al. 2001).

\subsubsection{Viruses}

Cases of livestock nematodes infected by nematopathogenic viruses have been reported (Stifling, 1991). One challenge is that it is difficult to recognize viral infection in microscopic nematodes, or differentiate sick nematodes from those that are diseased or immobile for some other reason (Waller and Faedo, 1996). Consequently, viral pathogens against free living stages of animal parasitic nematodes are unlikely to be developed as commercial products.

\subsubsection{The soil amoeba, Theratromyxa weberi Zwillenberg}

Theratromyxa weberi Zwillenberg can trap the nematode and digests it within a day. However, Gronvold at al. (1996) indicated that T. weberi and other amoebae have limited biological control capacity because they are slow-moving compared with nematodes, and they are sensitive to low soil water potentials, conditions under which nematodes may survive.

\subsubsection{Protozoa}

Protozoa have been used as biological control agents for nematodes and for insects control (Lacey et al., 2001). Most promising species seem to be those that produce spores which attack nematodes following ingestion. However, this ingestion is prevented in many nematode species by the narrow bore of their style canal (Waller and Faedo, 1996). For this reason, protozoa might not offer a high class opportunity for biological control of nematode parasites of livestock.

\subsubsection{Micro-arthropods}

A number of soil invertebrates have been tested for their potential as biological control of nematode parasites. Micro-arthropods such as collembolans and mites may be effective options. The mechanisms by which collembolans and mites affect nematodes have not yet been determined. Collembolans and mites are capable of consuming Ascaris suum eggs (Akhtar and Malik, 2000).

\subsubsection{The fungus Duddingtonia flagrans Cooke}

Use of nematophagous fungi may be a way to reduce pasture contamination and parasite populations. A number of fungal species have shown anthelmintics properties (Epe et al., 2009). These fungi are able to attract and kill the 
developing larval stages of parasitic nematodes in a faecal environment (Table 1.5), either as a primary source of nutrients or as a supplement to a saprophytic existence (Waller et al., 2006). According to their morphology, functional characteristics and the way they capture nematode parasites, these fungi are divided into three main classes: predacious, endo-parasitic and egg-destroying fungi (Waller and Faedo, 1996). The fungus Duddingtonia flagrans is one of the fungi that traps nematodes and has shown much promise as a biological agent. This fungus belongs to a heterogeneous group of fungi in the Deuteromycetes family (Waller et al., 2006). Specifically, D. flagrans is a predacious fungus that produces adhesive three dimensional hyphal networks during development, which trap the larval stages of nematodes (Campos et al., 2008).

This fungus has shown its ability to survive through the digestive system of ruminants as a resistant spore (chlamydospore) form (Manueli et al., 1999) and has demonstrated its potential to consistently and significantly reduce the numbers of infective Trichostrongyle larvae and most of the economically important gastrointestinal parasites, when applied in animals feed as fungal spores (Larsen, 1999). Knox and Faedo (2001) reported a reduction in nematode larvae count and an improvement in live weight gains in sheep fed a supplement containing $D$. flagrans chlamydospores compared to untreated sheep.

The dosage of $D$. flagrans spores which affect nematode parasites negatively has been reported in many studies. For example, a fungal dose of $5 \mathrm{~g}$ of grain/sheep per day for 2 consecutive days reduced larval numbers in faecal culture in an in vitro study (Waller et al., 2001). In addition, Larsen et al. (1998) demonstrated that sheep fed a dose of $5 \times 105 \mathrm{D}$. flagrans chlamydospores per day resulted in a substantial (more than $80 \%$ ) reduction in the number of infective larvae derived from nematode eggs in faeces. Moreover, dosing calves with $106 \mathrm{D}$. flagrans chlamydospores per kg BW daily was sufficient to significantly reduce herbage infectivity and subsequently infection levels (Sarkunas et al., 2000). Another study in the equine field reported that dosage of 2 x106 chlamydospores per $\mathrm{kg} \mathrm{BW}$ were effective in reducing numbers and transmission of equine nematode L3 stages from faecal pats to surrounding herbage (Baudena et al., 2000). More importantly, feeding of daily dosages of $2.5 \times 104$ to $5 \times 105$
D. flagrans chlamydospores per $\mathrm{kg} \mathrm{BW}$ can control larval stages of $H$. contortus in sheep (Peña et al., 2002).

Duddingtonia flagrans traps the free-living larval stages, which include eggs, L1 and L2 stages within the faecal deposit, and infective third-stage larvae on pastures. D. flagrans can survive passage through the gastrointestinal tract in the host and might be effective in trapping larvae present in faeces, thereby reducing pasture larval population. Consequently, chlamydospores are administered orally and deposited in faeces (Faedo et al. 1998).

\subsubsection{The fungus Clonostachys rosea f. rosea Schroers}

The fungus is also known as Gliocladium roseum Bain which belongs to the family Bionectriaceae, and the Order Hypocreales. It is widely distributed, facultative saprophyte in the soil. Clonostachys rosea f. rosea is a predacious fungus has a potential to control nematodes of plants and animals (Zhang et al., 2008). The fungus has shown its ability to survive through the digestive system of ruminants as chlamydospore form (Baloyi et al., 2012). The fungus also is able to attack many organisms, including other fungi, bacteria, insects and nematode parasites because it produces a wide range of volatile organic compounds. For example, $C$. rosea protects plants against Botrytis cinerea by suppressing spore production (Li et al., 2004). Its hyphae grow inside the conidia of Botrytis cinerea. In addition, a strain of $C$. rosea, IK726, isolated from barley roots infected with Fusarium culmorum was evaluated for its biological activity. The strain IK726 was found to be effective against seed-borne diseases of cereals under field conditions. Moreover, IK726 strain of $C$. rosea controlled Alternaria radicina Meier, Drechsler and Eddy on carrot seeds (Jensen et al. 2000).

The mode of action of $C$. rosea as biological control agent is not well understood. However, mycoparasitism, substrate competition, enzymatic activity and induced resistance are all thought to play a role (Lübeck et al., 2002). Production of secondary metabolites might provide antibiotic effect as is known for other biocontrol fungi (Roberti et al., 2008). Clonostachys rosea f. rosea conidia attach to the cuticle of nematodes, germinate and produce germ tubes, which then penetrate the host body, and kill the nematode (Zhang et al., 2008). 
Clonostachys rosea f. rosea produces cell walldegrading enzymes, including chitin, glucan, and cellulose-degrading enzymes (Roberti et al., 2008). The enzymatic hydrolysis of chitin is catalysed by the action of three types of chitin- hydrolysing enzymes belonging to glycosyl hydrolase families. These enzymes digest the cell walls of ascomycetes and basidiomycetes, as well as insect skeletons (Mamarabadi et al., 2009).

Table2. Fungal species used to control nematode parasites

\begin{tabular}{|c|c|c|}
\hline \multicolumn{2}{|l|}{ Fungal species } & Susceptible nematodes \\
\hline \multirow[t]{2}{*}{ Endoparasitic fungi } & Drechmeria & \multirow{2}{*}{$\begin{array}{l}\text { Heamoncus species and trichostrongylus } \\
\text { colubriformis }\end{array}$} \\
\hline & Harposporium anguillucal & \\
\hline Predacious fungi, & $\begin{array}{l}\text { Arthrobotry soligospora } \\
\text { Arthrobotry misinformis } \\
\text { Arthrobotry robusta } \\
\text { Monacrosporium } \\
\text { endermatum }\end{array}$ & $\begin{array}{l}\text { Ostertagia species } \\
\text { Dictyocalus villilpar } \\
\text { Heamoncus contortus } \\
\text { Oesophagostumum species } \\
\text { Cooperia Species }\end{array}$ \\
\hline \multicolumn{2}{|c|}{$\begin{array}{l}\text { Egg parasitic fungi } \\
\text { Vertisillium chlamydosporium }\end{array}$} & Ascaris suum \\
\hline
\end{tabular}

Source: Larsen, 2000

\subsubsection{The bacterium Bacillus thuringiensis Berliner}

Bacillus thuringiensis Berliner is a gram positive bacterium, found in various ecological niches such as soil, plant surfaces and dust from stored-products (Maagd et al., 2003). Bacillus thuringiensis is closely related to Bacillus cereus Frankland and Frankland, a soil bacterium, and Bacillus anthracis Koch, the cause of anthrax. The three organisms are mainly different in their plasmids (Helgason $e t$ al., 2000). Like other members of the genus, all three are aerobes capable of producing endospores.

Bacillus thuringiensis produces crystals of proteinaceous insecticidal $\delta$-endotoxins (crystal proteins or Cry proteins) (Ito et al., 2006). Cry toxins have specific toxin effects against insect species of the orders Lepidoptera, Diptera, Coleoptera, Hymenoptera, Homoptera, Orthoptera, and Mallophaga as well as other organisms such as nematodes, mites and protozoa (Maagd et al., 2003). Bacillus thuringiensis has received considerable attention because of its utility for control of insect pests in agriculture and insect vectors of human diseases (Maagd et al., 2003; Quesada-Moraga et al., 2004). Basically, B. thuringiensis strains have been used to control insect pests since the 1920s (Wood, 2002). Bacillus thuringiensis is considered safe to people and non-target species, such as wildlife. Its formulations can be used on all food crops, making it relatively easy to exploit commercially. Moreover, $B$. thuringiensis does not have dominant alleles, which could be easy to influence genetically (Raymond et al., 2010). Some B. thuringiensis strains can kill nematodes (Larsen, 1999). In addition, many $B$. thuringiensis isolates have been found to be highly toxic to larval stages and adults of $H$. contortus, $T$. colubriformis and $O$. circumcincta in vitro (Kotze et al., 2005). These studies indicated that $B$. thuringiensis is toxic to both larval stages and adults of economically significant nematodes (Table1.3). Therfore, B. thuringiensis strains could be utilized as anthelmintics to kill nematodes of the gastrointestinal tract, and/or the free-living larval stages that develop in faeces or on pastures.

Research on using $B$. thuringiensis to control the free-living larval stages of nematodes resulted in a significant reduction of existing parasites (Kotze et al., 2005). On the other hand, B. thuringiensis spores are slow to germinate and develop crystal toxins to disturb the nematode growth (Grady et al., 2007). Notably freshly hatched larvae are more susceptible to $B$. thuringiensis toxins than older ones. These constraints limit the ability of $B$. thuringiensis isolates to inhibit nematode populations (Grady et al., 2007). Wei et al. (2003) reported that $B$. thuringiensis uses the same mode of action to kill nematodes. Kotze et al. (2005) have shown that different $C r y$ proteins have variable toxicity towards nematodes. For example, Cry5B endotoxin kills Caenorhabditis elegans (Marroquin et al., 2000). Some protoxins 
Alternative Control Methods of Gastrointestinal Nematode Infections in Small Ruminants: Biological Method and Use of Medicinal Plant Extracts

Cry5B, Cry6A, Cry 14A and Cry21A are toxic to a number of free-living stages of nematodes, and Cry5B, Cry $14 A$ and Cry $21 A$ were highly toxic to the free-living larval stages of the rodent-parasitic nematode, Nippostrongylus brasiliensis (Wei et al., 2003). These studies have confirmed that Cry proteins cause damage to the intestine of both nematodes and insects.

Table3. Effect of biological control agents on nematodes

\begin{tabular}{|c|c|c|c|c|c|c|}
\hline \multirow{2}{*}{$\begin{array}{l}\text { Biocontrol } \\
\text { agent }\end{array}$} & \multirow{2}{*}{$\begin{array}{l}\text { Experimental } \\
\text { model }\end{array}$} & \multicolumn{4}{|c|}{ Effect on } & \multirow[t]{2}{*}{ Reference } \\
\hline & & EPG & LPG & WT & $\mathbf{L 3} *$ & \\
\hline $\begin{array}{l}\text { Arthobotrys } \\
\text { dactyloides }\end{array}$ & Goats and Sheep & & + & & & $\begin{array}{l}\text { Sandecris et al., } \\
2008\end{array}$ \\
\hline $\begin{array}{l}\text { Arthobotrys } \\
\text { oligospora }\end{array}$ & Cattle & & + & & & $\begin{array}{l}\text { Gronvold et al., } \\
1985\end{array}$ \\
\hline $\begin{array}{l}\text { Catenaria } \\
\text { anguillula }\end{array}$ & Goats and Sheep & & + & & & $\begin{array}{l}\text { Sandecris et al., } \\
2008\end{array}$ \\
\hline $\begin{array}{l}\text { Clonostachys } \\
\text { Rosea }\end{array}$ & Sheep & None & + & None & & $\begin{array}{lll}\text { Baloyi et al., } \\
2012\end{array}$ \\
\hline $\begin{array}{l}\text { Clonostachys } \\
\text { Rosea }\end{array}$ & $\begin{array}{l}(+) \\
\text { Plants }\end{array}$ & & & & & Li et al., 2004 \\
\hline $\begin{array}{l}\text { Duddingtonia } \\
\text { flagrans }\end{array}$ & Sheep & None & + & None & & Peña et al., 2002 \\
\hline $\begin{array}{l}\text { Duddingtonia } \\
\text { Flagrans }\end{array}$ & Goats & None & + & + & None & Epe et al., 2009 \\
\hline $\begin{array}{l}\text { Duddingtonia } \\
\text { Flagrans }\end{array}$ & Cattle & None & + & None & + & $\begin{array}{l}\text { Sarkunas et al., } \\
2000\end{array}$ \\
\hline $\begin{array}{l}\text { Duddingtonia } \\
\text { flagrans } \\
\end{array}$ & Horse & None & + & & + & $\begin{array}{l}\text { Fernández et al., } \\
1997\end{array}$ \\
\hline $\begin{array}{l}\text { Drechmeria } \\
\text { coniospora }\end{array}$ & In vitro & + & & & & $\begin{array}{l}\text { Santos and } \\
\text { Charles, } 1995\end{array}$ \\
\hline $\begin{array}{l}\text { Harposporium } \\
\text { anguillulae }\end{array}$ & Sheep & + & & & & $\begin{array}{l}\text { Charles et al., } \\
1996\end{array}$ \\
\hline $\begin{array}{l}\text { Bacillus } \\
\text { thuringiensis }\end{array}$ & Sheep & None & + & + & & Baloyi, 2011 \\
\hline $\begin{array}{l}\text { Bacillus } \\
\text { thuringiensis }\end{array}$ & Cattle & + & + & + & & $\begin{array}{l}\text { Ciordia and } \\
\text { Bizzell, } 1996\end{array}$ \\
\hline $\begin{array}{l}\text { Bacillus } \\
\text { thuringiensis }\end{array}$ & In vitro & + & + & & & $\begin{array}{l}\text { Kotze et } \quad \text { al., } \\
2005\end{array}$ \\
\hline
\end{tabular}

$\mathrm{EPG}=$ egg per gram of faeces; $\mathrm{LPG}=$ larvae per gram of faeces; WT= live weight; $*=\mathrm{L} 3$ from pasture; $+=$ reduction in $\mathrm{LPG}$; None $=$ no effect

\subsection{Medicinal Plants as Alternative to Chemotherapy}

\subsubsection{Use of plants as a source of phyto- medicines}

Since the time immemorial, our traditional system of medicine and folklore claiming that medicinal plants as a whole or their parts are being used in all types of disease successfully including anthelmintics (Jitendra et al., 2010). Plant-based drugs are believed to be less toxic to the host and end-users. They are easily available, biodegradable, cheaper and ecofriendly. Moreover, the people have used them for generations. Rural folk, tribes, ethnic groups and nomads have found several plants very effective for their day-to-day problems of health care. In livestock, medicinal plants are important in veterinary practice worldwide.
Therefore, Phytomedicines in veterinary practice have great potential as alternative medicine (Kumar et al., 2008). Unlike synthetic anthelmintics, Herbal medicines with different mode of action could be of value in preventing the development of the resistance (Singh et al., 2008)

Some devastating infectious diseases such as malaria, responsible for deaths of thousands of people can be overcome with traditional herbal anti-malarian drugs obtained from South America, Africa and Asia ie., Cinchona (Cinchona sp.), Qing hao (Artemisa annua), Changshan (Dichroa febrifuga), Neem (Azadirachtaindica), Cryptolepsis sanguinolenta) and other plants (Willcox et al., 2005). Researchers around the world have scientifically explored the real effect of many 
plants used as medicines whose uses are not validated by rigorous scientific experimentation. Many plants are being screened for antiparasitic effects on animals; since animal behaviour reveals self medication when animals select and ingest some specific plants (Cousing and Huffman, 2002; Huffman, 2003). During the last decades the study of medical principles from plants has gained considerable interest and a number of natural bio-active compounds from plant extracts are currently commercially available to cure many diseases (Sumer and Plutkin, 2000). Sinha parol et al. (2012) reported that plants are one of the most important sources of medicines. The medicinal plants are rich in secondary metabolites which are potential sources of drugs and essential oils of therapeutic importance. The important advantages claimed for therapeutic uses of medicinal plants in various ailments are their safety besides being economical, effective and bioavailable.

\subsubsection{Plant parts and methods of preparation of herbal medicine:}

Methods of preparation of traditional medicines varies according to the active ingredient to be extracted, the route of administration, and the medical intent For preparation of drugs, parts of the plants that are mostly utilized are roots, barks, wood, leaves, stems, flowers, fruits, juices, resins, latex, grains, buds, bulbs and seeds ( Jabbar et al., 2006a; Dilshad et al., 2008).

Main methods used for processing the herbal remedies were; decoction, maceration, poultices and ointment. Decoction; this process was used when working with tough and more fibrous plants/ parts such as the trunk bark and root bark. The materials were boiled in water for long period of time to soften the materials and release the active chemical constituents. Maceration was preferably used for very tender/fresh plants, that were thought to lose their active compounds on heating. The mashed or ground plant materials were stirred in water to make a concoction. The poultices were prepared by mashing fresh plant materials. The mashed material would be applied directly on the affected part [Allan, 2011]. The processing of the herbal remedies is diagrammatically described below by Allan, 2011.

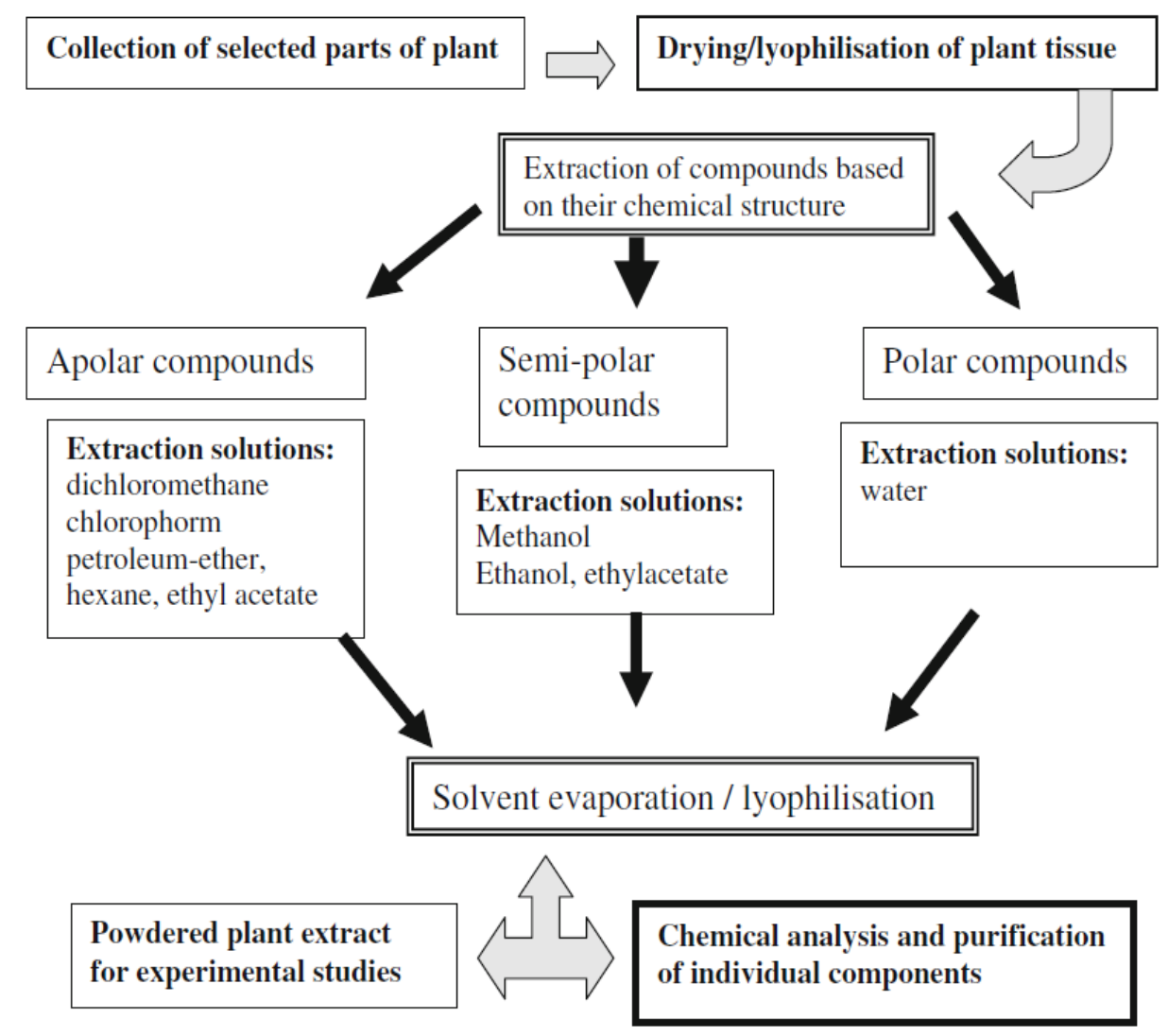

Figure2. Diagram showing the key steps of preparatory process for obtaining the single group of phytochemical /compound from the higher plants. 
As there are many ways of plants preparation, dosage form, risk of side effects, scientific verifications, for therapeutic use different Table4. Plants and plant preparations authors has been described the preparation in various ways as indicated in table 4.

\begin{tabular}{|c|c|c|c|c|c|}
\hline $\begin{array}{l}\text { Botanical \& } \\
\text { Common Name }\end{array}$ & Preparation & Dosage & $\begin{array}{l}\text { Risks, Side- } \\
\text { effects \& } \\
\text { Effectiveness } \\
\end{array}$ & \begin{tabular}{|l|} 
Scientific \\
Verification \& \\
Comment \\
\end{tabular} & Prime Source \\
\hline \multirow{4}{*}{$\begin{array}{l}\text { Allium sativum } \\
\text { Garlic }\end{array}$} & Crushed cloves & $\begin{array}{l}1 \mathrm{Tsp} / \\
\text { animal/day }\end{array}$ & \multirow{4}{*}{$\begin{array}{l}\text { No side-effects } \\
\text { known, further } \\
\text { investigation of } \\
\text { effects on } \\
\text { derogation of } \\
\text { milk-flavour, } \\
\text { Effective against } \\
\text { GIN and } \\
\text { lungworms }\end{array}$} & \multirow{4}{*}{$\begin{array}{l}\text { traditionally } \\
\text { applied In vivo } \\
\text { trial showed no } \\
\text { effect of garlic } \\
\text { administration } \\
\text { contradicting } \\
\text { statements of } \\
\text { the effectiveness }\end{array}$} & \multirow{4}{*}{$\begin{array}{l}\text { Allen, } 1998 \\
\text { Duval, } 1994 \\
\text { Cabaret et al., } \\
2002 \text { b } \\
\text { Meat New } \\
\text { Zealand, } 1998 \\
\text { Perezgroves, no } \\
\text { date } \\
\text { University of } \\
\text { Aberdeen, no } \\
\text { date }\end{array}$} \\
\hline & Dried powder & $\begin{array}{l}\text { Mixed in with } \\
\text { feed } \\
\text { Dosage not } \\
\text { specified } \\
\end{array}$ & & & \\
\hline & Juice & $\begin{array}{l}\text { Oral drench } \\
\text { Dosage not } \\
\text { specified }\end{array}$ & & & \\
\hline & Capsules & $\begin{array}{l}2-3 / \text { animal/ } \\
\text { day }\end{array}$ & & & \\
\hline $\begin{array}{l}\text { Annonum } \\
\text { senegalensis } \\
\text { Custard Tree }\end{array}$ & $\begin{array}{l}\text { Dried stem bark } \\
\text { extract }\end{array}$ & $\begin{array}{l}\text { Not specified } \\
\text { for living } \\
\text { animals }\end{array}$ & $\begin{array}{l}\text { No toxicity } \\
\text { noted }\end{array}$ & $\begin{array}{l}\text { Traditionally } \\
\text { used by } \\
\text { Nigerian } \\
\text { farmers } \\
\text { In vitro test } \\
\text { showed } \\
\text { promising } \\
\text { potential } \\
\end{array}$ & $\begin{array}{l}\text { Alawa et al., } \\
2003\end{array}$ \\
\hline $\begin{array}{l}\text { Artemisia } \\
\text { abrotanum } \\
\text { Southern } \\
\end{array}$ & Powdered herbs & $\begin{array}{l}1 \mathrm{Tbs} / \text { sheep/ } \\
\text { twice daily for } \\
\text { several days }\end{array}$ & $\begin{array}{l}\text { No toxicity } \\
\text { noted }\end{array}$ & $\begin{array}{l}\text { Although } \\
\text { traditionally } \\
\text { used, activity } \\
\end{array}$ & $\begin{array}{l}\text { Hoffmann, } 1995 \\
\text { in: Häublein, } \\
2005\end{array}$ \\
\hline
\end{tabular}

\subsubsection{Exploring the anti-parasitic properties of plants}

A wide range of plants and their products around the world are being explored to look for their possible anthelmintic effects on cestodes and trematodes (Abdel-Ghaffar et al., 2011), and against nematodes (Datsu Kalip et al., 2011). Due to the important economic impact of gastrointestinal parasitic nematodes in the livestock industry around the world, most of the research on plant extracts is being focused on searching bioactive compounds from plants against this important group of parasites.

Traditionally, some plants around the world are well known as anti-parasitic plants because they contain substances with anthelmintic effects against parasitic nematodes affecting agricultural crops (Krueger et al., 2009) or animal parasitic nematodes (De Jesús Gabino et al., 2010). Perhaps, the most known cases of plants with nematicidal properties around the world are garlic (Allium sativum) ( Qadir et al., 2010) Marigold (Tagetes erecta) (Krueger et al., 2009).

Another example is the South African plant Curtisia dentata commonly used for ages by rural communities as a remedy to cure a number of diseases caused by bacteria and fungi in either human being or animals (Shai et al., 2008) and against animal parasitic nematodes (Shai et al., 2009). Nevertheless, every year, the list of new plants with nematocidal in vitro and in vivo properties against animal parasites is growing as new natural alternatives for replacing (at least partially) the use of chemical drugs (Shai et al., 2009).

Some forage have been evaluated searching for potential bio-active compounds against sheep and goat parasitic nematodes with variable results. However studies must be intensified; since some individual limitations in application have been noticed; ie., toxicity, metabolic disorders and inappropriate applications can cause severe damage and even the death of treated animals (Rahmann and Seip, 2008). Other plants are being investigated as bio-active forages in the control of Haemonchus contortus in lambs with good/moderate results. For instance Wormwood (Artemisia absinthium) which was offered to lambs for voluntary intake, parasitic burden was reduced almost in $50 \%$. Additionally, faecal egg excretion expressed on a dry matter basis was also reduced by $73 \%$ in animals fed with the selected plant (Valderrábano et al., 2010).

Some plant extract have shown an extraordinary bio-activity against sheep parasitic nematodes; ie., supplementing sheep with a Fumaria parviflora ethanol extract eliminated fecal eggs and caused 72 and $88 \%$ mortality of adult Haemonchus contortus and Trichostrongylus colubriformis, respectively (Hördegen et al., 
2003). These are only a few examples of candidate plant extracts to be used in the control of parasites in sheep and goat farming. Rochfort et al (2008) from Australia published a very complete and extraordinary review about bioactive plants and their impact on animal health and productivity. On the other hand, Diehl et al (2004) published the results of a very interesting research project evaluating eighty six plant extracts from Ivory Coast flora and finding that fifty percent of the evaluated plants had nematocidal activity against Haemonchus contortus larvae. Such results showed evidence about the important nematocidal activity of plants from Ivory Coast as potential ethnobotanical tools of control against ruminant parasitic nematodes (Diehl et al., 2004).

Some recent reports of nematocidal activity of plant extracts against ruminant parasites in different countries are described as follows: In Ethiopia, extracts from $C$. macrostachyus and $E$. capensis have shown promising in vitro anthelmintic activity against eggs and adult $H$. contortus which supports the traditional use of these plants as anthelmintic (Mihretabs et al,.2011). In Pakistan, Adhatodavasica both aqueous and ethanolic extracts exhibit an in vitro ovicidal and larvicidal activity ranging between $81-89 \%$ against diverse genera/specie of gastrointestinal parasitic nematodes of sheep (Al-Shaibani et al., 2008). In Burkina, Faso, two medicinal plants Anogeissus leiocarpus and Daniellia oliveri were analyzed to identify their anthelmintic effect against nematodes of sheep abomasum. A. leiocarpus and D. oliveri showed a maximum lethal activity, between 80 and $100 \%$ respectively, against adult Haemonchuscontortus (Aldama et al., 2009; Kaboure et al., 2009).

Many countries have developed important screening of plant extracts with anthelmintic properties from their native flora with an enormous potential for the control of animal parasitic nematodes with encouraging results. These countries such as Brazil, India, South Africa, China and others possesses an extraordinary richness in their medicinal flora and they have currently developed an important industry from plant extracts ably supported by science. Some researchers stand out for their important contributions in this regard: Githiori et al (2006) at the International Livestock Research Institute in Nairobi, Kenya; Iqbal et al (2001) and his group or researchers from the
Department of Veterinary Parasitology, University of Agriculture, Faisalabad, Pakistan have developed a solid package of information about a big list of native plants with encouraging results in the control of GI parasites ( Bachaya et al., 2009).

\subsubsection{Condensed tannin-rich plants}

A number of research works have focused on the anthelmintic effect of tannin rich plants against GIN. This group of bio-active compounds present in selected plant material are being obtained from all over the world, from temperate areas well as from tropical tannin rich fodders (Alonso-Diaz et al., 2010).

Interdisciplinary groups of researchers (Hoste et al., 2006; Alonso Díaz et al., 2008; CalderónQuintal et al., 2010; Martínez-Ortíz-deMontellano et al., 2010) have developed important research studies on tannin-rich plants in the control of $H$. contortus and other important gastrointestinal nematodes. Most scientific works focused on identifying the bioactive compounds produced by nematocidal plants have reported the presence of different molecules including catechins, condensed tannins, flavonoids and steroids (Oliveira et al., 2009) and polyphenolics (Lorimer et al., 1996); as well as bio-active enzymes such as cystein protease and secondary metabolites such as alkaloids, glycosides and tannins (Athanasiadou and Kvriazakis, 2004). Further in-depth studies need to be undertaken since even though antiparasitic properties are being demonstrated, negative effects such as reduction in food intake by animals have been identified and this should be considered before establishing their use as an alternative method of control (Githiori et al., 2006).

Up to date studies, researchers are reaching beyond the general knowledge about lethal in vitro activity of plants and bio-active compounds derived from selected plants against themost important nematode parasites of ruminants. New efforts are being carried out to find practical applications of plants or plant products in the control of ruminant parasitic nematodes; including ways and means of overcoming limitations in applications to animals (Rahmann and Seipa, 2008). Recently in Laos, reduction in appearance of nematode eggs on goat feces with the Cassava foliage 
Alternative Control Methods of Gastrointestinal Nematode Infections in Small Ruminants: Biological Method and Use of Medicinal Plant Extracts

supplement has been demonstrated (Phengvichith and Preston, 2011). Some plant extracts used in vitro to control gastrointestinal nematodes in animals around the world is discussed by different authors in the table below.

Table 5. Some plant extracts used in vitro to control gastrointestinal nematodes in animals around the world

\begin{tabular}{|c|c|c|c|c|c|}
\hline Plant family & $\begin{array}{l}\text { Plant scientific } \\
\text { name }\end{array}$ & Country of Use & $\begin{array}{l}\text { Method of } \\
\text { Preparation }\end{array}$ & Claims & References \\
\hline Asphodelaceae & Aloe ferox & South Africa & Leaf extract & Effective & $\begin{array}{l}\text { Maphosa et al., } \\
2010\end{array}$ \\
\hline Liliaceae & Allium sativum & Pakistan & $\begin{array}{l}\text { Water extract of } \\
\text { the garlic bulb }\end{array}$ & Effective & Iqbal et al., 2001 \\
\hline Moraceae & Ficus spp. & Not stated & Juice extract & Effective & $\begin{array}{lll}\text { Gillian } & \text { et } & \text { al., } \\
2004 & & \end{array}$ \\
\hline Bromeliaceae & Ananas comosus & \begin{tabular}{|l} 
Pakistan \\
Philippines
\end{tabular} & Raw powder & Ineffective & $\begin{array}{l}\text { Hördegen et al., } \\
2003 \text {. }\end{array}$ \\
\hline Zingiberaceae & $\begin{array}{l}\text { Zingiber } \\
\text { officinale }\end{array}$ & Pakistan & $\begin{array}{l}\text { Ethanol extract of } \\
\text { Rhizomes }\end{array}$ & Effective & Iqbal et al., 2001 \\
\hline Leguminosae & $\begin{array}{l}\text { Tephrosia } \\
\text { vogelli }\end{array}$ & Ethiopia & $\begin{array}{l}\text { Ethanol extract of } \\
\text { leaves }\end{array}$ & Effective & $\begin{array}{l}\text { Siamba et al., } \\
2007\end{array}$ \\
\hline Amaranthaceae & $\begin{array}{l}\text { Halothamnus } \\
\text { somaliensis }\end{array}$ & Ethiopia & $\begin{array}{l}\text { Crude preparation } \\
\text { of roots powder }\end{array}$ & Effective & $\begin{array}{l}\text { Dawo and Tibbo, } \\
2005\end{array}$ \\
\hline Leguminosae & $\begin{array}{l}\text { Ornobrychis } \\
\text { viciafolia }\end{array}$ & France & $\begin{array}{l}\text { Aqueous acetone } \\
\text { extract }\end{array}$ & Effective & $\begin{array}{l}\text { Paolini et al., } \\
2003\end{array}$ \\
\hline Fabaceae & $\begin{array}{l}\text { Elephantorrhiza } \\
\text { elephantina }\end{array}$ & South Africa & $\begin{array}{l}\text { Aqueous extract } \\
\text { of leaves }\end{array}$ & $\begin{array}{l}\text { Effective with } \\
\text { high doses }\end{array}$ & $\begin{array}{l}\text { Maphosa et al., } \\
2010\end{array}$ \\
\hline Mimosaceae & $\begin{array}{l}\text { Albizia } \\
\text { anthelmintica }\end{array}$ & $\begin{array}{lr}\text { East } & \text { Africa, } \\
\text { Kenya, Sweden, } \\
\text { Ethiopia, Uganda }\end{array}$ & $\begin{array}{l}\text { Heat treated or } \\
\text { soaked in water }\end{array}$ & Ineffective & Longok, 2002 \\
\hline
\end{tabular}

\section{CONCLUSION AND RECOMMENDATIONS}

Parasitic nematodes remain a major threat to the health and welfare of small ruminants all over the world and the demand for alternative control measures has constantly increased during the last years. Infestation with GIN parasites can have severe consequences for the animal as well as for the livestock farmers leading to economic loss and restricted productivity. The use of chemical anthelmintic drugs for controlling animal parasitic nematodes is rapidly losing popularity due to a number of disadvantages. Anthelmintic resistance in the parasites is spreading and the inefficacy of chemical antiparasitic compounds is threatening animal health. New plants with medicinal properties against parasites of ruminants are being investigated around the world with promising results. When plant/plant extracts are being selected for use as anti-parasitic drugs in sheep a particular attention should be given to the fact that the bio-active compound could be found in stems, roots, leaves, flowers, fruits or even in the entire plant. This means that obtaining plant extracts is a laborious and complex process. Also, the mode of extraction and the solvent used can determine the success in isolating the expected bioactive compounds; since a wide variety of compounds can be hidden into the structural parts of the plants and the only way they could be isolated is through exploring the use of a range of organic solvents. Therefore, in the near future natural products obtained from plants extracts seems that likely will become a viable alternative of control of parasitizes of veterinary importance. Although a lot of research has been done on biological control options the outcome of this area of investigation proved rather disillusioning.

Based on the aforementioned scientific information gathered, the following points could be recommended:

* Any approach related to the current parasite control options should be studied in detail taking into considerations of the global threats of drug resistance against many of the antihelmentiscs. 
Since promising results have already been documented on the use of biological control methods and medicinal plant products, further study must be intensified to produce, low cost but effective and user friendly control methods.

\section{REFERENCES}

[1] Abdel-Ghaffar, F., Semmler, M., Khaled, A., Al-Rasheid, S., Strassen, B., Fischer, K., Aksu, G., Klimpel, S., Mehlhorn, H. (2011) The effects of different plant extracts on intestinal cestodes and on trematodes. Parasitology Research (2011) 108:979-984.

[2] Abuda R, Gebreyohannes M, Mekuria S, Abuna F, Regassa A (2010). Gastrointestinal nematode infections in small ruminants under traditional husbandry system during dry seasons in Southern Ethiopia. Trop. Anim. Health. Prod. 42: 1111-1117.

[3] Agyei, A.D.(1997). Seasonal changes in the level of infective Strongylate nematode larvae on pasture in the coastal savanna regions of Ghana. Veterinary Parasitology 70: 175-182.

[4] Akhtar, M. and Malik, A. (2000). Roles of organic soil amendments and soil organisms in the biological control of plant-parasitic nematodes: A review. Bioresource Technology 74:35-47.

[5] Akhtar, M.S. and Riffat, S. 1984. Efficacy of Melia azedarach Linn.fruit (Bahain) and Morantel against naturally acquired gastrointestinal nematodes in goats. Pakistan Veterinary Journal, 4: 176-9.

[6] Alawa C.B.I., Adamu, A. M. Gefu, J. O., Ajanvis, O. T., Abdu, P. A. C hiwzey, N. P. Alawa, J. N. and Bowmn, D. D. (2003): Invite screening of two Nigerian medicinal plants for anthemintic activity Vet. Parasitol.113: $73-81$

[7] Aldama, K., Belem A. M. Gaston, M., Hamidou, H., Amadou, T., and Sawadogo Laya, S. (2009) In vitro anthelmintic effect of two medicinal plants (Anogeissus leiocarpus and Daniellia oliveri) on Haemonchus contortus, an abosomal nematode of sheep in Burkina Faso. African Journal of Biotechnology 8 (18)4690-4695.

[8] Allan C (2011). A primer on medicinal plants for livestock Health Care. Animal Scientist/ Extension Specialist Northern Marians College Cooperative Research Extension and Education service, Philippine.

[9] Allen, J. (1998) Study of Alternative Parasitides for Organic Lamb Production. Organic Farming Research Foundation Project Report. www.organicaginfo.org/ record.cfm? $\mathrm{p}$ k_doc_id $=343 \&$ doc_num $=13$
[10] Alonso-Díaz, M.A., Torres-Acosta, J.F.J., Sandoval-Castro, C.A., Capetillo-Leal, C., Brunet, S., Hoste, H. (2008) Effects of four tropical tanniniferous plant extracts on the inhibition of larval migration and the exsheathment process of Trichostrongyluscolu briformis infective stage. Veterinary Parasitology 153:187-192.

[11] Al-Shaibani, I.R.M., Phulan, M.S., Arijoand, A., Qureshi, A. (2008) Ovicidal and larvicidal properties of Adhatoda vasica (L.) extracts against gastrointestinal nematodes of sheep in vitro. Pakistan Veterinary Journal. 28(2): 7983.

[12] Athanasiadou, S. Githiori, J. and Kyriazakis, I. (2007). Medicinal plants for helminth parasit control: facts and fiction. Animal,1(9): 13921400

[13] Athanasiadou, S., Kvriazakis. I. (2004) Plant secondary metabolites: antiparasitic effects and their role in ruminant production systems. Proceedings of the Nutrition Society. 63(4): 631-639.

[14] Bachaya, H.A., Z. Iqbal, M.N. Khan, A. Jabbar, A.H. Gilani and I.U. Din, 2009. In vitro and In vivo anthelmintic activity of Terminalia arjunabark. International Journal ofAgricultural Biology, 11: 273-278.

[15] Baloyi, M.A.(2011). Biological control of gastrointestinal nematodes using Bacillus thuringiensis (Berliner) and Paecilomyces lilacinus (Samson). MSc thesis (Plant Pathology), Pietermaritzburg, South Africa

[16] Baloyi, M.A. Laing, M.D. and Yobo, K.S.(2012).Use of mixed cultures of biocontrol agents to control sheep nematodes. Veterinary Parasitology 184: 367-370.

[17] Besier, R.B. and Love, S.C.(2003). Anthelminthic resistance in sheep nematodes in Australia: The need for new approaches. Australian Journal of Experimental Agriculture 43:1383-1391.

[18] Cabaret, J., Bouilhol, M., Mage, C. (2002b).Managing helminths of ruminants in organic farming.Veterinary Research 33: 625640.

[19] Calderón-Quintal, J.A., Torres-Acosta, J.F.J., Sandoval-Castro, C.A., Alonso-Díaz, M.A., Hoste, H., Aguilar-Caballero, A. (2010) Adaptation of Haemonchus contortus to condensed tannins: can it be possible? Archives of Medical Veterinary 42, 165-171.

[20] Chartier C, Soubirac F, Pors I, Silvestre A, Hubert J, Couquet C and Cabaret J (2001). Prevalence of anthelmintic resistance in gastrointestinal nematodes of dairy goats under extensive management conditions in southwestern France. Journal of Helminthology vol. 75 no. 4 pp 325-330(6). 
[21] Chartier, C., Pors, I., Hubert, J., Rocheteau, D., Benoit, C. and Bernard, N.(1998).Prevalence of anthelmintic resistant nematodes in sheep and goats in western France. Small Ruminant Research 29: 33-41.

[22] Ciordia, H. and Bizzell, W.E. (1961).A preliminary report on the effects of Bacillus thuringiensis Berliner on the development of free-living stages of some cattle nematodes.Journal of Parasitology 47: 41 (abstract).

[23] Coffey, L., Hale, M., Terrill, T.H., Mosjidis, J.A., Miller, J.E. and Burke, J.M.(2007). Tools for managing internal parasites in small ruminants: Sericea lespedeza. http://www.attra.ncat. org/attrapub/sericea_lespedeza.html accessed on 10/12/2010.

[24] Coop, R.L. and Kyriazakis, I.(2001). Influence of host nutrition on the development and consequences of nematodes parasitism in ruminants. Trends in Parasitology 17:325-330.

[25] Cousins, D. and Huffman, A.M. (2002) Medicinal properties in the diet of Gorillas: An ethno-pharmacological evaluation. African Study Monographs, 23(2): 65-89.

[26] Datsu Kalip, R., Slyranda Baltini, A., Wycliff, A., Abdulrahaman, F.I. (2011) Preliminary phytochemical screening and in vitro anthelmintic effects of aqueous extracts of Salvadora persica and Terminalia avicennoides against strongyline nematodes of small ruminants in Nigeria. Journal of Animal and Veterinary Advances. 10(4):437-442.

[27] Dawo, F. and Tibbo, M.(2005).Anthelmintic effect of Halothamus somalensis in Arsi-Bale goats. Livestock Research for Rural Development

17:http://www.lrrd.org/lrrd17/6/dawo17068.ht $\mathrm{m}$ accessed on 14/06/2010.

[28] De Jesús Gabino, A.F., Mendoza de Gives, P., Salinas Sánchez, D.O., López Arellano, Ma. E., Liébano Hernández, E., Hernández Velázquez, V.M. and Valladares Cisneros, G. (2010) Anthelmintic effects of Prosopis laevigata nhexanic extract against Haemonchus contortus in artificially infected gerbils (Meriones unguiculatus) Journal of Helminthology 84:7175.

[29] De, S. and Sanyal, P.K.(2009).Biological control of helminth parasites by predatory fungi. Vetscan 4:1-8.

[30] Diehl, M.S., Kamanzi Atindehou, K., Téré, H., Betschart, B. (2004) Prospect foranthelminthic plants in the Ivory Coast using ethnobotanical criteria. Journal of Ethnopharmacology 95(23)277-284.

[31] Duval, J. (1994) the control of internal parasitesinruminants.www.eap.mcgill.ca/Agro
Bio/ab370

04e.htm\#BOTANICAL\%20DEWORMERS

[32] Eguale T, Tilahun G, Debella A, Feleke A, Makonnen E (2007a) In vitro and in vivo anthelmintic activity of crude extracts of Coriandrum sativum against Haemonchus contortus. J Ethnopharmacol 110:428-433. doi:10.1016/j.jep.2006.10.003

[33] Epe, C., Holst, C., Koopmann, R., Schnieder, T., Larsen, $M$. and Von SamsonHimmelstjerna, G.(2009). Experiences with Duddingtonia flagrans administration to parasitized small ruminants. Veterinary Parasitology 159: 86-90.

[34] Fernandez, A.S., Larsen, M., Nansen, P., Grønvold, J., Henriksen, S.A. and Wolstrup, J. (1997). Effect of the nematode-trapping fungus Duddingtonia flagrans on the free-living stages of horse parasitic nematodes: A plot study. Veterinary Parasitology 73: 257-66.

[35] Gadahi JA, Arshed MJ, Ali Q, Javaid SB, Shab SI (2009). Prevalence of gastrointestinal parasites of sheep and goats in and around Rawalpindi and Islamabadi, Pakistan. Vet. World Res. 2: 51-53.

[36] Getachew T. Dorchies P. and Jacquiet P. (2007): Trend and challenges in the effective and sustainable control of Haemonchus contortus infection in sheep 14: 3 - 14 .

[37] Githiori, B.J., Athanasiadou, S. and Thamsborg, M.S. (2006) Use of plants in novel approaches for control of gastrointestinal helminths in livestock with emphasis on small ruminants. Veterinary Parasitology 139(4):30820.

[38] Grady, J.O., Akhurst, R.J. and Kotze, A.C. (2007).The requirement for early exposure of Haemonchus contortus larvae to Bacillus thuringiensis for effective inhibition of larval development. Veterinary Parasitology 150: 97103.

[39] Gronvold, J., Henriksen, S.A., Larsen, M., Nansen, P. and Wolstrup, J. (1996). Biological control: Aspects of biological control, with special reference to arthropods, protozoans and helminths of domesticated animals. Veterinary Parasitology 64: 47-64.

[40] Gronvold, J., Korsholm, H., Wolstrup, J., Nansen, P. and Henriksen, S.A. (1985). Laboratory experiments to evaluate the ability of Arthobotrys oligospora to destroy infective larvae of Cooperia species and to investigate the effect of physical factors on the growth of the fungus. Journal of Helminthology 59:119126.

[41] Hale, M. (2006). Managing internal parasites in sheep and goats.http:// www.attra. ncat.org/ attra-pub/PDF/ parasitesheep.pdf accessed on 21/10/2009. 
[42] Häublein, K. (2005). Alternative Endoparasiten kontrolle bei Schafen. Diplomar beit. Fachbereich Ökologische Agrarwissen schaft en, Universität Kassel.

[43] Helgason, E., Andreas Økstad, O., Caugant, D.A., Johansen, H.A., Fouet, A., Mock, M., Hegna, I. and Brit Kolstø, A. (2000). Bacillus anthracis, Bacillus cereus, and Bacillus thuringiensis - one species on the basis of genetic evidence. Applied and Environmental Microbiology 66: 2627-2630.

[44] Hördegen, P., H. Hertzberg, J. Heilmann, W. Langhans and V. Maurer, (2003). The anthelmintic efficacy of five plant products against gastrointestinal trichostrongylids in artificially infected lambs. Veterinary Parasitology, 117: 51-60.

[45] Hoste, H., Jackson, F., Athanasiadou, S., Thamsborg, M.S. and O. Hoskin, O.S. (2006) The effects of tannin-rich plants on parasitic nematodes in ruminants. Trends in Parasitology, 22(6):253-261.

[46] Huffman, F. A. (2003) Animal self-medication and ethno-medicine: exploration and exploitation of the medicinal properties of plants. Proceedings of the Nutrition Society 62(2):371-381.

[47] Iqbal Z, Lateef $M$, Ashraf $M$ and Jabbar A 2004.Anthelmintic activity of Artemisia brevifolia in sheep. Journal of Ethnopharmacology 93, 265-268.

[48] Iqbal, Z., Nadeem, Q.K., Khan, M.N., Akhtar, M.S. and Waraich, F.N. (2001).In vitro anthelmintic activity of Allium sativum, Zingiber officinale, Curcurbita mexicana and Ficus religiosa. International Journal of Agriculture and Biology 3: 454-457.

[49] Ito, T., Ikeya, T., Sahara, K., Bando, H. and Asano, S. (2006). Cloning and expression of two crystal protein genes, Cry30Bal and Cry44Aal, obtained from a highly mosquitocidal strain, Bacillus thuringiensis subsp. entomocidus INA288. Applied Environmental Microbiology 72: 5673-5676.

[50] Jabbar A, Zaman MA, Iqbal Z, Yassen M, Shamim A (2007) Anthelmintic activity of Chemopodium album (L) and Caesalpinia crista (L) against trichostrongylid nematodes of sheep. J Ethnopharmacol 114: 86-91

[51] Jitendra patel, G. S. Kumar, md Shamim Qureshi, P. K. Jena (2010): International Journal of phyto medicine 2, 127 - 132.

[52] Kaboure, A., Belem A. M. G., Gaston, M., Tamboura H. H., Traore, A. and Sawadogo, L. (2009) In vitro anthelmintic effect of two medicinal plants (Anogeissus leiocarpus and Daniellia oliveri) on Haemonchus contortus, an abomasal nematode of sheep in Burkina Faso.
African Journal of Biotechnology 8 (18): 46904695.

[53] Knox, M.R. and Faedo, M. (2001). Biological control of field infections of nematode parasites of young sheep with Duddingtonia flagrans and effects of spore intake on efficacy. Veterinary Parasitology 101: 155-160.

[54] Kotze, A.C., Grady, J., Gough, J.M., Pearson, R., Bagnall, N.H., Kemp, D.H. and Akhurst, R.J. (2005). Toxicity of Bacillus thuringiensis to parasitic and free-living life stages of economically important nematode parasites of livestock. International Journal of Parasitology 35: 1013-1022.

[55] Krueger, R., Dover, E.K., McSorley, R., Wang, K-H.(2009) Marigold (Tagetes spp) for nematode management.University of Florida IFAS Extension, Publication ENY- 056.

[56] Larsen M. (2000): Prospects for controlling animal parasitic nematodes by predacious micro fungi parasitology, 20: 5121 - 5131 .

[57] Larsen, M. (1999).Biological control of helminths. International Journal for Parasitology 29: 139-146.

[58] Larsen, M. (2006).Biological control of nematode parasites in sheep. Journal of Animal Science 84: 133-139.

[59] Lorimer, D.S., Perry, B.N., Foster, M.L. and Burgess, E. (1996) A Nematode Larval Motility Inhibition Assay for Screening Plant Extracts and Natural Products. Journal of Agriculture Food Chemistry, 1996, 44 (9), pp 2842-2845

[60] Maagd, R.A., Bravo, A., Berry, C., Crickmore, N. and Schnepf, H.E. (2003).Structure, diversity, and evolution of protein toxins from spore-forming entomopathogenic bacteria. Annual Review of Genetics 37: 409-433.

[61] Maphosa, V., Masika, P.J., Bizimenyera, E.S. and Eloff, J.N. (2010).In vitro anthelminthic activity of crude aqueous extracts of Aloe ferox, Leonotis leonurus and Elephantorrhiza elephantina against Haemonchus contortus. Tropical Animal Health and Production 42: 301-307.

[62] Marroquin, L.D., Elyassnia, D., Griffitts, J.S., Feitelson, J.S. and Aroian, R.V. (2000).Bacillus thuringiensis (Bt) toxin susceptibility and isolation of resistance mutants in the nematode Caenorhabditis elegans. Journal of Genetics 155: 1693-1699.

[63] Martínez-Ortíz-de-Montellano, C., VargasMagaña, J.J., Canul-Ku, H.L., MirandaSoberanis, R., Capetillo-Leal, C., SandovalCastro, C.A., Hoste, H. and Torres- Acosta, J.F.J. (2010) Effect of a tropical tannin-rich plant Lysiloma latisiliquum on adult populations of Haemonchus contortus in sheep. Veterinary Parasitology 172(3- 4):283-90. 
[64] .Mihreteab, B., G. Tilahun, K. Yisehak and A. Mesele, 2011.In-vitro anthelmintic activity of condensed tannins from Rhus glutinosa, Syzygium guineenses and Albizia gummifera against sheep Haemonchus contortus.Glob. Veteri, 6: 476-484.

[65] Min, B.R. and Hart, S.P. (2003).Tannins for suppression of internal parasites. Journal of Animal Science 81: 102-109.

[66] Mitreva, M., Zarlenga, D.S., McCarter, J.P. and Jasmer, D.P. (2007).Parasitic nematodes-from genomes to control. Veterinary Parasitology 148: 31-42.

[67] Oliveira, L.M.B., Bevilaqua, C.M.L., Costa, C.T.C., Macedo, I.T.F., Barros, R.S., Rodrigues, A.C.M., Camurca-Vasconcelos, A.L.F., Morais, S.M., Lima, Y.C., Vieira, L.S., Navarro, A.M.C.(2009) Anthelmintic activity of Cocos nucifera L. against sheep gastrointestinal nematodes. Veterinary Parasitology 159, 55-59.

[68] Paolini, V., Dorchies, P. and Hoste, H. (2003). Effects of sainfoin hay on gastrointestinal nematodes in goats. Veterinary Research 152: 600-601.

[69] Peña, M.T., Miller, J.E., Fontenot, M.E., Gillespie, A. and Larsen, M. (2002).Evaluation of Duddingtonia flagrans in reducing infective larvae of Haemonchus contortus in feces of sheep. Veterinary Parasitology 103: 259-265.

[70] Perry, B. D., Randolph, T. F., McDermott, J. J., Sones, K. R. \& Thornton, P. K. 2002.Investing in animal health research to alleviate poverty. ILRI (International Livestock Research Institute), Nairobi, Kenya, 148 pp. ISBN 9291461083.

[71] Phengvichith, V. and Preston, R.T. (2011) Effect of feeding processed cassava foliage on growth performance and nematode parasite infestation of local goats in Laos.Livestock Research for Rural Development 23(1).

[72] .Qadir, S., Dixit, K.A., Dixit, P. (2010) Use of medicinal plants to control Haemonchus contortus infection in small ruminants. Veterinary World, 3(11)515-518.

[73] Quesada-Moraga, E., García-Tóvar, E., Valverde-García, P. and Santiago-Álvarez, C. (2004).Isolation, geographical diversity and insecticidal activity of Bacillus thuringiensis from soils in Spain. Microbiological Research 159: 59-71.

[74] Rahmann, G. and Seip, H. (2008) :Bioactive forage and phytotherapy to cure and control endo-parasite diseases in sheep and goat farming systems - a review of current scientific knowledge. In: Landbauforschung Völkenrode. Bundesforschungsanstalt für Landwirtschaft, pp. 285-295.
[75] Raymond, B., Wyres, K.L., Sheppard, S.K., Ellis, R.J. and Bonsall, M.B. (2010). Environmental factors determining the epidemiology and population genetic structure of the Bacillus cereus group in the field. Journal of PLoS Pathogens 6: (5). available at http://www.lrrd.org/lrrd19/12/ siam19176.htm accessed date 21/7/2010.

[76] Rochfort, S., Parker, J.A., Dunshea, R.F. (2008) Plant bioactives for ruminant health and productivity. Phytochemistry 69 (2008) 299322.

[77] Sandecris, C.V., Liberty, G.T. and Jonar, I.Y. (2008). Occurrence of nematode-trapping fungi in goat (Capra hircus) and sheep (Ovis aries). NVSU Research Journal XV: 1-2.

[78] Santos, C.P. and Charles, T.P. (1995).Effect of an endo-parasitic fungus, Drechmeria coniospora, in faecal cultures containing eggs of Haemonchus contortus. Arquivo Brasileiro de Medicina Veterinaria Zootecnia 47: 123128.

[79] Sarkunas, M., Larsen, M., Nansen, P. and Hansen, J.W. (2000).Biological control of trichostrongyle infections in calves on pasture in Lithuania using Duddingtonia flagrans, a nematode-trapping fungus. Journal of Helminthology 74: 355-359.

[80] Scheuerle, M.C. (2009). Anthelmintic resistance of Haemonchus contortus and the Famacha Method as a tool to delay the development of anthelminthic resistance.MSc Thesis (biology), Faculty of Veterinary Medicine, Ludwig Maximilian University, Munich, Germany.

[81] Shai, L.J., Bizimenyera, E.S., Bagla, V., McGaw, L.J., Eloff, J.N. (2009) Curtisia dentate (Cornaceae) leaf extracts and isolated compounds inhibit motility of parasitic andfreeliving nematodes. Onderstepoort Journal of Veterinary Research, 76(2):249-56.

[82] Shai, L.J., McGaw, L.J., Aderogba, M.A., Mdee, L.K., Eloff, J.N. (2008) Four pentacyclic triterpenoids with antifungal and antibacterial activity from Curtisia dentate (Burm.f) C.A. Sm. Leaves. Journal of Ethnopharmacology. 26,119(2):238-44.

[83] Siamba, D.N., Okitoi, L.O., Watai, M.K., Wachira, A.M., Lukibisi, F.B. and Mukisira, E.A. (2007).Efficacy of Tephrosia vogelli and Vernonia amygdalina as anthelmintics against Ascaridia galli in indigenous chicken. Livestock Research for Rural Development 19: Article No. 176.

[84] Simcock, D.C., Scott, I., Przemeck, S.M. and Simpson, H.V. (2006). Abomasal contents of parasitised sheep contain an inhibitor of gastrin secretion in vitro. Research in Veterinary Science 81: 225-230. 
[85] Singh, T.U., Kumar, D., Tandan, S.K. and Mishra, S.K. (2009).Inhibitory effect of essential oils of Allium sativum and Piper longum on spontaneous muscular activity of liver fluke, Fasciola gigantica. Experimental Parasitology 123: 302-308.

[86] Stromberg, B.E. and Averbeck, G.A. (1999).The role of parasite epidemiology in the management of grazing cattle. International Journal for Parasitology 29: 33.-39.

[87] Sumer, J. and Plutkin, M (2000) Chimpazees and self-medication. In: The Natural History of Medicinal Plants Timber Press Inc. Portland, Oregon, USA.

[88] Thamsborg, S.M., Roepstorff, A. and Larsen, M. (1999).Integrated and biological control of parasites in organic and conventional production systems. Veterinary Parasitology 84: 169-186.

[89] Thomas, G.W., Cooper, B. and Lauckner, B. (2001) Preliminary investigation into the use of neem as an anthelmintic for the control of gastro-intestinal parasites of small ruminants (online).Antigua, zufindenin available at http//WWW.agriculture.gov.bb/files/Neem.pdf accessed on 24.4.2010.

[90] Tsotetsi, A. M. \& Mbati, P. A., Parasitic helminths of veterinary importance in cattle, sheep and goats on communal farms in the north-eastern Free State, South Africa. Journal of South African Veterinary Association 74, 4548.

[91] Valderrábano, J., Calvete, C. Uriarte, C. (2010) Effect of feeding bioactive forages on infection and subsequent development of Haemonchus contortus in lamb faeces. Veterinary Parasitology, 172 (1-2)89-94.
[92] Viassoff, A., Leathwick, D.M. and Heath, A.C. (2001).The epidemiology of nematode infections of sheep. New Zealand Veterinary Journal 49: 213-221.

[93] Waller P. Sustainable helminth control of ruminants in developing countries. Vet Parsitol 1997; 71: 195-207.

[94] Waller, P. J. 2003. International approaches to the concept of integrated control of nematode parasites of livestock. International Journal for Parasitology 29, 155-164.

[95] Waller, P.J. (2006). Sustainable nematode parasite control strategies for ruminant livestock by grazing management and biological control. Animal Feed Science and Technology 126: 277-289.

[96] Waller, P.J. and Faedo, M. (1996).The prospects for biological control of the freeliving stages of nematode parasites of livestock. International Journal for Parasitology 26: $915-$ 925.

[97] Wei, J.Z., Hale, K., Carta, L., Platzer, E., Wong, C., Fang, S.C. and Aroian, R.V. (2003).Bacillus thuringiensis crystal proteins that target nematodes. National Academy of Science USA 100: 2760-2765.

[98] Wolstenholme, A.J., Fairweather, L., Prichard, R.K., Samson-Himmelstjerna, G.V. and Sangster, N.C. (2004).Drug resistance in veterinary helminths. Trends in Parasitology 20: 469-476.

[99] Wood, B.J. (2002). Pest control in Malaysia's perennial crops: A half century perspective tracking the pathway to integrated pest management. Integrated Pest Management Reviews 7: 173-190.

Citation: Ermias Worku, Ashenafi Kiros, Hagos Asgedom, Biniam Tadesse. Alternative Control Methods of Gastrointestinal Nematode Infections in Small Ruminants: Biological Method and Use of Medicinal Plant Extracts. ARC Journal of Animal and Veterinary Sciences. 2017; 3(2):11-27. doi: dx.doi.org/ 10.20431/24552518.0302002.

Copyright: (C) 2017 Authors. This is an open-access article distributed under the terms of the Creative Commons Attribution License, which permits unrestricted use, distribution, and reproduction in any medium, provided the original author and source are credited. 